\title{
Bibliografia historii wychowania (druki zwarte wydane w Polsce w l. 1995-1996)
}

50 lat Szkoly Muzycznej im. Józefa Elsnera w Warszawie, Warszawa 1996, ss. 218;

90 lat ZNP w kraju: 1905 - 1995. 67 lat Oddziahu Wolsztyńskiego ZNP: $1928-1995.50$ lat ZNP na Ziemi Lubuskiej: 1945 - 1995, Wolsztyn 1995, ss. 90;

Absolwenci, doktoraty i habilitacje Wydzialu Rolniczo-Leśnego i Leśnego Uniwersytetu Poznańskiego oraz Wydzialu Leśnego Wyższej Szkoly Rolniczej i Akademii Rolniczej w latach 1919-1994, red. Meisner J., Poznań 1995, ss. 150 ;

Akademia Muzyczna w Poznaniu w latach 1920 -1995, red. Brodniewicz T., Poznań 1995, ss. 272 ;

Akademia Zamojska w dziejach $i$ życiu miasta, red. Szczygieł R., Urbański A., Zamość 1996;

Ariês P., Historia dzieciństwa. Dziecko i rodzina w dawnych czasach, przek. Ochab M., Gdanisk 1995, ss. 239;

Balicki M., Szkolnictwo bialostockie w latach 1944-1972. Studium historyczno-porównawcze, Białystok 1995, ss. 222;

Banaszek M., Powstanie $i$ dzialalność ruchu nauczycielskiego $w$ warunkach okupacji austriackiej (1915 - 1918) na przykladzie Ostrowieckiego Towarzystwa Nauczycielskiego i Oddzialu Zrzeszenia PNSP w Ostrowcu, Ostrowiec Swiętokrzyski 1995, ss. 32;

Baran A.F., $Z$ dziejów harcerstwa tarnobrzeskiego 1912-1949, Tarnobrzeg 1995, ss. 99;

Batko F., Kartka z historii Szkoly Ślusarskiej w Swiqtnikach, Kraków 1995, ss. 61;

Białobocki A., Absolwenci Gimnazjum i Liceum Swietej Marii Magdaleny w Poznaniu 1805 -1950, Poznań 1995, ss. 227;

Bielecki J., Olga Malkowska harcmistrzyni Rzeczypospolitej, Bielsko-Biała 1995, ss. 135;
Budzyn B., The Polish Technical College in Esslingen/Germany 1945-1949, Kraków 1996, ss. 274;

Chachaj M., Zagraniczna edukacja Radziwillów od poczatku XV do polowy XVI wieku, Lublin 1995, ss. 171;

Chmiel A., Pieczecie Uniwersytetu Jagiellonskiego w Krakowie, oprac. Piech Z., Kraków 1996, ss. 122;

Doroszewski J., Praca oświatowa i kulturalna na Lubelszczyźnie w latach II Rzeczypospolitej, Lublin 1995, ss. 203;

Dutkowa R., Polityka szkolna w Galicji między autonomiq a centralizmem (1861-1875), Kraków 1995, ss. 171;

Dutkowa R., Żeńskie gimnazja Krakowa w procesie emancypacji kobiet (1896-1918), Kraków 1995, ss. 116;

Dzieje Akademii Wychowania Fizycznego w Poznaniu (1919-1994), red. Gaj J., Poznań 1996, ss. 296;

II Ogólnopolski Zjazd Pedagogiczny. Demokracja a wychowanie, Materiały przedzjazdowe, Toruń 1995, ss. 234;

Gamulczak F., Rozwój polskiej myśli pedagogicznej o edukacji dzieci i mlodzieży $z$ dysfunkcja narzqdu ruchu w latach $1918-1993$, Warszawa 1995, ss. 212;

Gawlik S., Dziedzictwo pedagogiczne Klementyny z Tariskich Hoffmanowej, Opole 1995, ss. 117 ;

Grochowski L., Studia z dziejów polskiej szkoly $i$ pedagogiki lat międzywojennych $w$ kontekście europejskim, Warszawa 1996, ss. 187;

Gromadzka E., Z historii Szkoly Rolniczej w Lowiczu-Blichu 1925 - 1995, Lowicz 1995, ss. 46; 
Grześ B., Deportacja nauczycieli do ZSRR 1939-1941, Warszawa 1995, ss. 158 ;

Hellwig J., Prolegomena do historii wychowania, Poznań 1995, ss. 121;

Hejnicka-Bezwińska T., Pedagogika ogólna. Tradycja - teraźniejszość - nowe wyzwania (materiały pokonferencyjne), Bydgoszcz 1995, ss. 329;

Historia ojców $i$ ojcowstwa, red. Delumeau J., Roche D., Warszawa 1995, ss. 476;

Historyczne zródla wybranych ofert edukacyjnych w Polsce wspólczesnej. Materiały z konferencji naukowej nt „Teoretyczne i praktyczne oferty edukacyjne we współczesnej pedagogice i ich żródła historyczne", red. Drynda D. i in., Katowice 1996, ss. 154;

Jakubowski M., Janusz Korczak i jego dokonania, Częstochowa 1996, ss. 264;

Jałmużna T., Z dziejów akademickiej Lodzi. Wyższa Szkola Pedagogiczna 1946-1956. Lódź 1996 , ss. 127 ;

Jasiński Z, Redziński K., Polscy uchodźcy i polskie szkoly w Czechach i na Morawach w czasie I wojny swiatowej, Opole 1995, ss. 104;

Jezuicka ars educandi. Prace ofiarowane Ksiedzu Prof. Ludwikowi Piechnikowi SJ, Kraków 1995 , ss. 288;

Jundzitł J., Rodzina rzymska w czasach prosperity i przemian ideowych II wieku. Apulejusz, Fronton, Marek Aureliusz i Tertulian, Bydgoszcz 1996, ss. 284;

Kądzielski S., Stużyli polskiej szkole. Sylwetki naucz ycieli $i$ dzialaczy oświatowych oraz Zwiqzku Nauczycielstwa Polskiego Srodkowego Nadodrza z lat 1945 -1993, Zielona Góra 1995, ss. 126;

Karolewicz G., Nauczyciele akademiccy Katolickiego Uniwersytetu Ludowego w okresie miedzywojennym, cz. 1 Lublin 1996, ss. 258; cz. 2: Biogramy, Lublin 1996, ss. 251;

Kawka M., Szkoly rolnicze w Lublinie i Lubyczy Królewskiej 1944-1994, Lubycza Królewska 1995, ss. 159;
Kazanowski K., Martyrologia nauczycieli w Lubelskiem w latach II wojny światowej, Lublin 1995, ss. 89;

Korczak J., Pamietnik, Wrocław 1996, ss. 87;

Kotlarski J., Politechnika Gdaniska 1945-1952. Nasza Polibuda, Gdańsk 1995, ss. 97;

Koźmian D., Chrzescijańska myśl wychowawcza Fryderyka Wilhelma Foerstera $i$ jej recepcja w Polsce, Szczecin 1996, ss. 169;

Krawczyk J, Galicyjskie szkolnictwo zawodowe w latach 1860-1918, Kraków 1995, ss. 295;

Krupiński W., Jan Galisz SJ pedagog jezuicki XIX wieku, Kraków 1996, ss. 122;

Ksiega Jubileuszowa 50-lecia Politechniki Wroclawskiej 1945 -1995, Wrocław 1995, ss. 20;

Ksztalcenie artystyczne w Winie i jego tradycje. Katalog wystawy Torun 15 marca - 5 maja 1996, Wino 7 czerwca - 7 lipca 1996, red. Malinowski J. i in., Torun 1996, ss. 408;

Kucha R., Szkolnictwo Lublina w latach 1864 - 1915. Zarys dziejów, Lublin 1995, ss. 348;

Kuciński J., Kalendarium tradycji akademickich w Lodzi ( $X V-X X$ wiek), Lódź 1995, ss. 28;

Kulczykowski M., Zydzi - studenci Uniwersytetu Jagiellońskiego $w$ dobie autonomicznej Galicji (1867-1918), Kraków 1995, ss. 435;

Kuryło-Omelianiuk J., Romanowska E., Zaniewska T., Historia Wychowania. Przewodnik, Białystok 1996, ss. 154;

Lec Z., Jezuici we Wroclawiu 1581 - 1776, Wroclaw 1995, ss. 195;

Lewicki S., Konrad Pruszyński (Kazimierz Promyk), Warszawa 1996, ss. 290;

Lwów - miasto, spoleczeństwo, kultura. Studia $z$ dziejów Lwowa, red. Żalińskiego H. i Karolczaka K, Kraków 1995, ss. 176;

Lyskawa M., Nauczyciele okregu szkolnego szczecińskiego w latach 1945 - 1993. Rozwój grupy spoleczno-zawodowej, Szczecin 1995, ss. 258;

Malinowska G., Pamiętnik kresowej nauczycielki z lat 1833 -1921, Bydgoszcz 1995, ss. 107; 
Marek-Ruka M., Kazimierz Kirejczyk. Zycie $i$ dzialalnosć, Warszawa 1995, ss. 42;

Markowski M., Dzieje Wydzialu Teologii Uniwersytetu Krakowskiego w latach 1397-1525, Kraków 1996, ss. 292;

Materialy do ćwiczeń z historii wychowania, red. Śnieciński J.M., cz. 3, Warszawa 1995, ss. 138;

Materialy do dziejów szkolnictwa na Mazowszu. Wypisy $z$ archiwaliów diecezjalnych $X I X$ wieku, przyg. Grzybowski M. M., Lowicz 1995, ss. 441;

Mietz A., Pawlak M., Szczotkowska-Topić M., Gimnazjum i Liceum im. ks. Jana Dlugosza we Woclawku 1916-1949, Bydgoszcz 1995, ss. 177 ;

Nauka i oswiata, red. Meissner A. i Wyrozumski J. (w: Galicja i jej dziedzictwo, t. III), Rzeszów 1995, ss. 286;

Nowak B., Ciechończyk L., Liceum Ogólnoksztalcqce im. Janusza Korczaka w Więcborku, Więcbork 1995, ss. 88;

Obirek S., Jezuici na dworach Batorego i Wazów 1580-1668. Wplyw kapelanów dworskich $i$ wychowawców ksiqżat na postawy panujacych i polityke państwa, Kraków 1996, ss. 99;

Obirek S., Wizja państwa u nauczaniu jezuitów polskich w latach 1564 -1668, Kraków 1995, ss. 71;

Oświata $i$ nauka na Ślqsku Opolskim (1945-1995), red. Gawlik S, Opole 1995, ss. 364 ;

Pauli H., Szkolnictwo rolnicze w Boleslawowie w latach 1945 -1995. VI Jubileuszowy Zjazd Absolwentów, Bolesławowo 1995, ss. 125;

Perkowska U., Studia $i$ kursy zawodowe na Uniwersytecie Jagiellonskim w latach 1868/69 - 1938/39, Kraków 1995, ss. 122;

Piech S., Dzieje wydziału Teologicznego Uniwersytetu Jagiellońskiego w latach 1880-1939, Kraków 1995, ss. 258;

Podstepne uwięzienie profesorów Uniwersytetu Jagiellońskiego i Akademii Górniczej (6 XI 1939 r.). Dokumenty, oprac. Buszko J., Paczyńska I, Kraków 1995, ss. 947;
Polskie Korporacje Uniwersyteckie, red. Ter-Uganjan L, z. 9. Zwiqzek Polskich Korporacji Uniwersyteckich w latach 1928-1939, oprac. Poplawski Z., Warszawa 1995, ss. 142 ;

Popiel J., Tajne nauczanie $w$ Zólkwi w latach 1939 -1944, Zabrze 1996, ss. 30;

Pracownicy nauki i dydaktyki Uniwersytetu Mikolaja Kopernika 1945 - 1994. Materialy do biografii, oprac. Duczkowska-Moraczewska H., Golembiowski M., Karpiesiuk R, red. Kalembka S., Toruń 1995, ss. 800;

Profesor Bogdan Suchodolski - jego filozofia, myśl pedagogiczna i dzialalnosć, red. Wojnar I., Kwiatkowska $H_{\text {, }}$ Kwieciński $Z$, Warszawa 1996, ss. 168;

Profesor Eugenia Podgórska, red. T. Jałmużna, Lódź 1995, ss. 19;

Riché P., Edukacja i kultura w Europie Zachodniej $И-V I I$ wieku, Warszawa 1995, ss. 557;

Rodzina a wychowanie - ciaglość i zmienność na przestrzeni wieków, red. Jundziłł J., Bydgoszcz 1995, ss. 144;

Rodzina jako środowisko wychowawcze w czasach nowożytnych, red. Jakubiak K., Bydgoszcz 1995, ss. 304;

Rodzina jako środowisko wychowawcze w czasach nowożytnych - koncepcje teoretyczne i pra$k t y k a, T e z y$ i streszczenia referatów, Bydgoszcz 1995, ss. 126;

Rodzina w spoleczenstwach antycznych $i$ wczesnym chrzescijaństwie, Literatura, prawo, epigrafika, sztuka, red. Jundziłł J, Bydgoszcz 1995, ss. 346;

Rybicki S.R., Pedagogika Jana de la Salle. Psychologiczne zalożenia lasaliańskiego systemu wychowawczego, Kraków 1996, ss. 166;

Rynio A., Wychowanie mlodzieży w nauczaniu Kardynala Stefana Wyszyńskiego, Lublin 1995, ss. 338;

Ryś J., Szkolnictwo parafialne w miastach Malopolski w XV wieku, Warszawa 1995, ss. 150;

Skowroński Z., Odlowy z oceanu wspomnień, Komorniki 1995, ss. 185; 
Slownik biograficzny nauczycieli w Malopolsce w latach II wojny swiatowej (1939-1945). Ofiary wojny, żolnierze, dzialacze konspiracyjni. nauczyciele $w$ jawnym $i$ tajnym szkolnictwie, oprac. Chrobaczyński J., Kraków 1995, ss. 584;

Stan $i$ perspektywy historii wychowania, red. Jamrożek W., Poznań 1995, ss. 155;

Strzelecki R., Teatr seminaryjny w Polsce w latach 1945-1988, Rzeszów 1995, ss. 230;

Szkola kaliska. Nauczyciele i wychowankowie. Zestaw hasel i materialy pomocnicze, red. Walczak K, Kalisz 1995, ss. 21;

Szkola Rolnicza w Czernichowie im. Franciszka Stefczyka. Zarys historii (1860-1995), Czernichów 1995, ss. 70;

Szkolnictwo wyższe w Kaliszu. Tradycje $i$ perspektywy, red. Jankowski D., Molenda H., Kalisz 1995, ss. 139;

Szlakami przeszlosci i czasów wspólczesnych, red Puchowski K., Zerko J., Gdańsk 1996, ss. 387 ;

Szorc A., Kopiczko A., Wyższe Seminarium Duchowne „Hosianum". Zarys dziejów, Olsztyn 1995, ss. 168;

Szulakiewicz W., Madyslaw Seredyński, Studium $z$ dziejów pedagogiki galicyjskiej (w: Galicja $i$ jej dziedzictwo, t. VII), Rzeszów 1995, ss. 166 ;

Tadeusz Lopuszański i dzielo jego życia. Szkola doświadczalna Gimnazjum i Liceum im. Sulkowskich w Rydzynie, red. Wierzbicki Z.T., Gliński J.B., Gludziński P., Warszawa 1995, ss. 101;
Uniwersytet Mikolaja Kopernika. Wspomnienia pracowników, red. Tomczak A., Toruń 1995, ss. 434;

Uniwersytet Whoclawski w okresie centralizmu stalinowskiego 1950-1955, oprac. Suleja T., Wrocław 1995 , ss. 320 ,

Walasek S., Szkolnictwo srednie ogólnoksztalcace na ziemiach polskich w latach 1914-1923, Wrockaw 1996;

Wincenciak W., $Z$ dziejów ksztalcenia nauczycieli w Eomży (1914-1994), Lomża 1996, ss. 196;

W kręgu akademickiego Zamościa, red. Gmiterek H., Lublin 1996, ss. 344;

$Z$ dziejów edukacji w Polsce XVII wieku, red. Szybiak I., Warszawa 1995, ss. 87;

$Z$ dziejów Almae Matris Vilnensis. Ksiega $\mathrm{Pa}$ miqtkowa ku czci 400-lecia zalożenia i 75-lecia wskrzeszenia Uniwersytetu Wileńskiego, red. Piechnik L. SJ i Puchowski K., Kraków 1996, ss. 426 ;

Zlotkowski D., Zycie zawodowe i rodzinne Stanislawa Polakowskiego 1880 - 1943 - nauczyciela szkól wiejskich, w swietle jego notatek $i$ korespondencji, Częstochowa 1995, ss. 119;

Źródla do dziejów wychowania i mysli pedagogicznej, oprac. Woloszyn S., t. I, Kielce 1995, ss. 695 ;

Zołądź-Strzelczyk D, Peregrinatio academica. Studia mlodzieży polskiej z Korony i Litwy na akademiach $i$ uniwersytetach niemieckich $w X V$ i pierwszej polowie XVI wieku, Poznań 1996, ss. 241. 